\title{
Faktor Kepuasan Pasien Terhadap Pelayanan Makanan Di Rumah Sakit: Literature Review
}

\section{Patient Satisfaction Factors for Food Service In Hospital: Literature Review}

\section{Zidni Ilma Nafi’a}

Program Studi Magister Kesehatan Masyarakat, Fakultas Kesehatan Masyarakat, Universitas Ahmad Dahlan email: ilmanafiazidni27@gmail.com

Jl. Prof. DR. Soepomo Sh, Warungboto, Kec. Umbulharjo, Kota Yogyakarta, Daerah Istimewa Yogyakarta

\begin{abstract}
ABSTRAK
Pelayanan makanan rumah sakit semakin berkembang untuk memenuhi indikator kinerja utama dalam kesehatan, sehingga pengukuran manfaat layanan makanan yang komprehensif sangat penting. Pelayanan makanan rumah sakit memegang peranan penting dalam kepuasan pasien. Kepuasan pasien tentunya berpengaruh indikator kinerja dan capaian rumah sakit. Tujuan literature review ini untuk mengetahui faktor kepuasan pasien terhadap pelayanan makanan di rumah sakit. Penelitian ini merupakan penelitian kualitatif deskriptif dengan model analisis literature review menggunakan prinsip Bagan Alur PRISMA. Sumber artikel berasal dari database online: PubMed, Science Direct, dan Google_Scholar. Kata kunci yang digunakan dalam mencari artikel adalah hospital food service and patient satisfaction, factor patient satisfaction and hospital food service, dan faktor kepuasan pasien terhadap pelayanan makanan rumah sakit. Sebanyak 120 artikel diperoleh berdasarkan penelusuran. Setelah melalui proses seleksi dan berdasarkan kriteria inklusi, diperoleh 10 artikel yang layak untuk direview. Hasil penelitian menunjukkan kualitas makanan (rasa, tekstur, penampilan, variasi, dan kebersihan) dan kualitas pelayanan makanan (sistem pelayanan makanan, peralatan makan, sikap dan kinerja staf) merupakan faktor-faktor kepuasan pasien terhadap pelayanan makanan di rumah sakit. Kualitas makanan dan kualitas pelayanan makanan merupakan faktor kepuasan pasien, sehingga perlu dilakukan evaluasi dan evaluasi secara berkala.
\end{abstract}

Kata kunci: Pelayanan Makanan, Kualitas Makanan, Kualitas Pelayanan Makanan, Kepuasan Pasien Rawat Inap

\section{ABSTRACT}

Hospital food service is increasingly evolving to meet key performance indicators in health, so a comprehensive measurement of the benefits of food service is essential. Hospital food service plays an essential role in patient satisfaction. Patient satisfaction certainly affects the hospital's performance indicators and achievements. This literature review aims. This research is descriptive qualitative research with a literature review analysis model using the PRISMA Flowchart principle. Article sources come from online databases: PubMed, Science Direct, and Google Scholar. The keywords used in searching for articles are hospital food service and patient satisfaction, patient satisfaction and hospital food service factors, and patient satisfaction factors with hospital food services. A total of 120 articles were obtained based on searches. After going through the selection process and based on the inclusion criteria, 10 articles were obtained worthy of review. The results showed that food quality (taste, texture, appearance, variety, and cleanliness) and food service quality (food service system, tableware, staff attitudes, and performance) were factors of patient satisfaction with food service in hospitals. Food quality and food service quality are factors of patient satisfaction, so it is necessary to evaluate and evaluate regularly.

Keywords: Hospital Food Service, Hospital Patient Food Quality, Food Service Quality, Inpatient Satisfaction 


\section{PENDAHULUAN}

Pelayanan kesehatan di rumah sakit terdiri dari beragam bagian salah satunya adalah pelayanan gizi. Program pelayanan gizi rumah sakit bertujuan untuk meningkatkan kualitas pelayanan rumah sakit melalui upaya penyediaan pelayanan gizi yang efisien dan terintegrasi dengan pelayanan kesehatan lainnya. Pelayanan gizi di rumah sakit merupakan bagian penunjang pelayanan kesehatan yaitu bagian dari terapi medis (Simanjuntak et al., 2020). Kegiatan pelayanan gizi rumah sakit terdiri dari asuhan gizi rawat jalan, asuhan gizi rawat inap, penyelenggaraan makanan, dan penelitian serta pengembangan (Yuwono et al., 2013). Pelayanan makanan bagi pasien merupakan bagian dari penyelenggaran makanan di rumah sakit.

Layanan makanan rumah sakit memainkan peran penting dalam proses pengobatan pasien selama rawat inap yaitu dengan memberikan makanan bergizi. Pelayanan makanan rumah sakit dimaksudkan untuk memberikan makanan yang higienis, aman, dan bergizi seimbang kepada pasien yang mendukung pemulihan pasien. Layanan makanan rumah sakit merupakan bidang yang kompleks dan membutuhkan keterampilan khusus. Ahli gizi dituntut memberikan layanan yang sesuai dengan jenis pasien, jenis pengobatan, dan meminimalisir terjadinya infeksi (Ramesh \& Manimegalai, 2018). Hal tersebut sesuai dengan konsep pelayanan gizi di rumah sakit yaitu pelayanan yang diberikan dan disesuaikan dengan keadaan pasien berdasarkan keadaan klinis, status gizi, dan status metabolisme tubuh. Keadaan gizi pasien sangat berpengaruh pada proses penyembuhan penyakit, sebaliknya proses perjalanan penyakit dapat berpengaruh terhadap keadaan gizi pasien. Sering terjadi kondisi pasien yang semakin buruk, karena tidak tercukupinya kebutuhan zat gizi untuk perbaikan organ tubuh. Fungsi organ yang terganggu akan lebih memburuk dengan adanya penyakit dan kekurangan gizi (Yuwono et al., 2013).

Kondisi internal pasien yang dirawat inap seringkali memengaruhi nafsu makan yang berdampak pada tingginya sisa makanan pasien meskipun demikian, faktor eksternal juga berpengaruh secara signifikan terhadap sisa makanan pasien. Kondisi fisik, kebiasaan makan, dan perbedaan jenis kelamin menjadi faktor internal yang menyebabkan pasien menyisakan makanan. Adapun faktor eksternal yang dominan memengaruhi pasien menyisakan makanan di rumah sakit adalah rasa makanan, penampilan makanan, dan kurangnya variasi makanan. Selain itu, peranan keluarga yang memberikan makanan dari luar rumah sakit, membantu, dan memberi motivasi pasien 
juga menjadi faktor yang berpengaruh terhadap pasien menyisakan makanan (Karunia Tanuwijaya et al., 2018).

Pentingnya pelayanan gizi di rumah sakit besar pengaruhnya terhadap kepuasan dan persepsi pasien terhadap rumah sakit. Kepuasan merupakan fungsi dari kesan kinerja dan harapan. Apabila kinerja layanan kesehatan yang diperoleh sama atau melebihi harapan, maka akan menimbulkan kepuasan terhadap pasien. Ketidakpuasan pasien akan muncul apabila kinerja layanan kesehatan yang diperoleh tidak sesuai dengan harapannya. Kualitas pelayanan yang baik akan memengaruhi kepuasan pasien dan pasien akan cenderung kembali datang untuk menggunakan jasa pelayanan tersebut (Arifiyanti et al., 2017). Kepuasan dan persepsi pasien bukan suatu hal yang sepele bagi rumah sakit, karena berkaitan dengan citra rumah sakit di masyarakat dan penilaian rumah sakit baik saat akreditasi maupun kegiatan sejenis lainnnya. Terkadang persepsi awal yang muncul pada pasien rawat inap adalah tentang bagaimana makanan yang nantinya diberikan, tak jarang yang beranggapan bahwa makanan rumah sakit tidak enak dan tidak sedikit pasien yang nakal dengan mengonsumsi makanan yang dibeli dari luar rumah sakit tentu jika tidak hati-hati kejadian tersebut dapat membahayakan kondisi pasien.

Aspek penting yang mempengaruhi kepuasan pasien di rumah sakit adalah hubungan pasien dengan makanan dan nutrisi dalam perawatan di rumah sakit (Messina et al., 2013). Terdapat dua faktor yang bisa mempengaruhi kepuasan pasien atas pelayanan makanan di rumah sakit yaitu karakteristik makanan dan distribusi makanan (Mangunsong \& Junadi, 2018). Kedua faktor tersebut merupakan bagian dari beberapa faktor lainnya dalam proses pelayanan makanan di rumah sakit sehingga dirasa masih perlu mengidentifikasi faktor - faktor yang berpengaruh besar terhadap kepuasan pasien di rumah sakit. Tujuan dari literature review ini adalah untuk mengetahui faktor kepuasan pasien terhadap pelayanan makanan di rumah sakit.

\section{METODE}

Penelitian ini merupakan penelitian kualitatif deskriptif dengan model analisis Literature Review yang mana bagan alur prosesnya tercantum pada Gambar 1 di bawah ini. Adapaun yang menjadi sumber data pada penelitian ini ialah artikel yang diunduh dari PubMed, ScienceDirect, dan GoogleScholar. Kata kunci yang digunakan untuk mencari artikel adalah hospital food service and patient satisfaction, factor patient satisfaction and hospital food service, dan faktor kepuasan pasien terhadap pelayanan makanan rumah sakit. Artikel di skrinning berdasarkan ketentuan sebagai berikut: 1) 
Merupakan artikel penelitian yang terbit dalam jurnal dengan rentang tahun 2010-2020, 2) Artikel penelitian yang diterbitkan di jurnal yang memiliki akses terbuka. 3) Artikel penelitian dengan Bahasa Indonesia atau Bahasa Inggris. Adapun kriteria egibilitas terdiri dari: 1) Penelitian berlangsung di rumah sakit, 2) Penelitian membahas kegiatan pelayanan makanan, 3) Hasil penelitian menampilkan faktor determinan kepuasan pasien, 4) Artikel dengan desain penelitian observasional analitik.

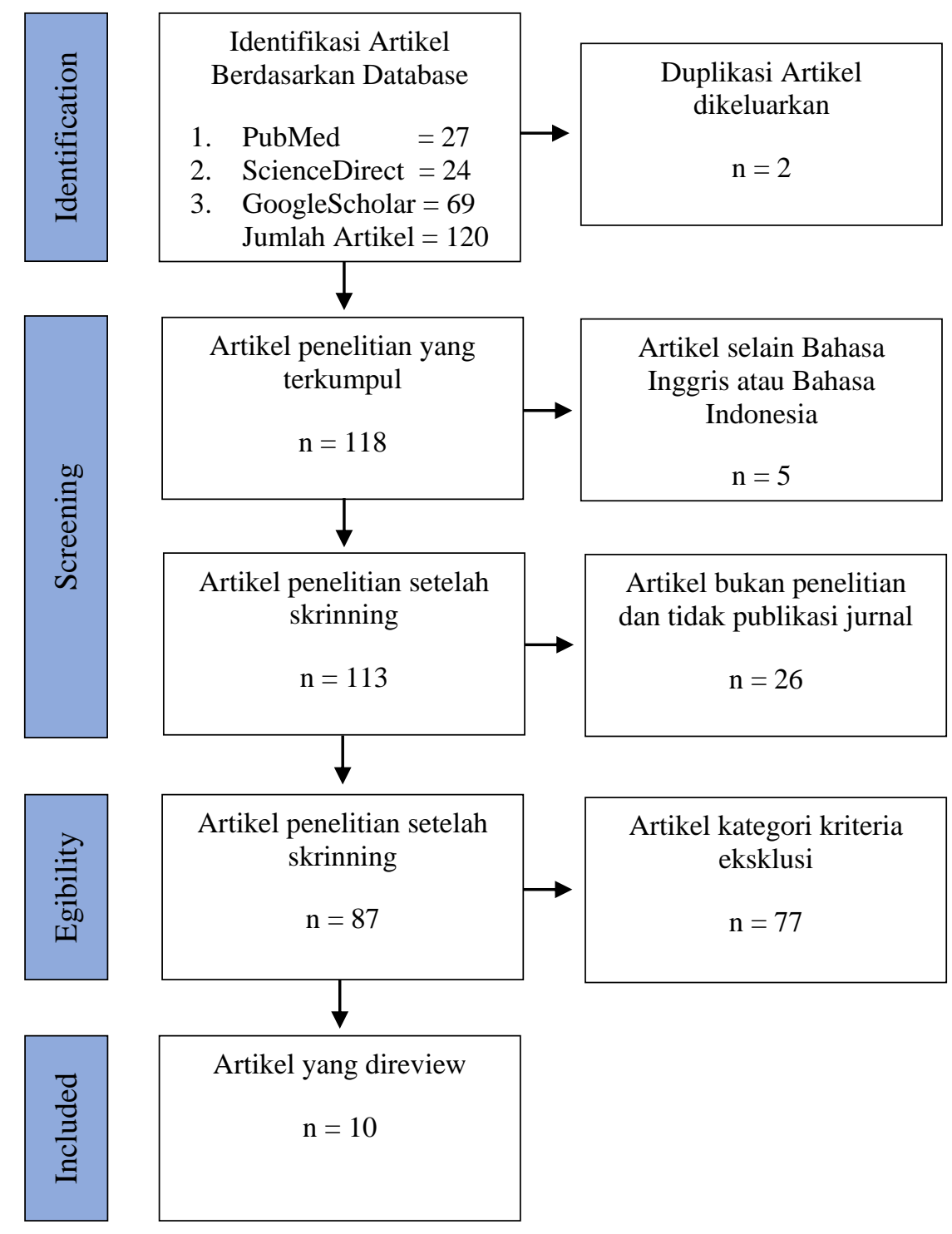

Gambar 1. Bagan Alur PRISMA Artikel Penelitian Faktor Kepuasan Pasien terhadap Pelayanan Makanan di Rumah Sakit 
Zidni Ilma Nafi'a : Faktor Kepuasan Pasien Terhadap Pelayanan Makanan ....

\section{HASIL}

Berdasarkan hasil identifikasi pencarian artikel diperoleh 120 artikel. Sebanyak 27 artikel diperoleh dari PubMed, 24 artikel diperoleh dari ScienceDirect, dan 69 artikel diperoleh dari GoogleScholar. Artikel kemudian disaring berdasarkan bahasa, jenis artikel, dan terbit di jurnal atau tidak sehingga diperoleh 87 artikel penelitian. Dari 87 artikel penelitian berdasarkan kriteria inklusi diperoleh 10 artikel penelitian yang dapat direview. Adapun rincian 10 artikel tersebut ialah 2 artikel dari PubMed dan 10 artikel dari GoogleScholar. Ringkasan keseluruhan hasil telaah artikel ditampilkan dalam Tabel 1. 
Jurnal Manajemen Kesehatan Yayasan RS. Dr. Soetomo Vol.7 No.2 Oktober 2021: 233-247

\begin{tabular}{|c|c|c|c|}
\hline 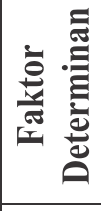 & 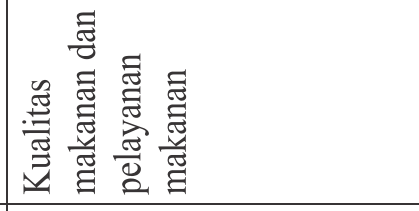 & 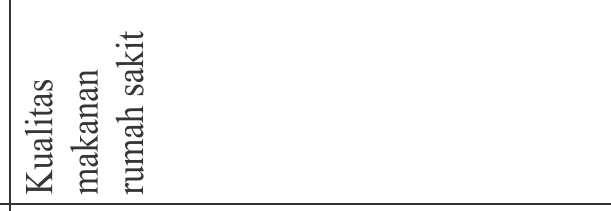 & 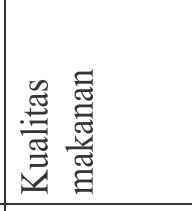 \\
\hline \begin{tabular}{|l}
$\overline{\bar{g}}$ \\
馬
\end{tabular} & 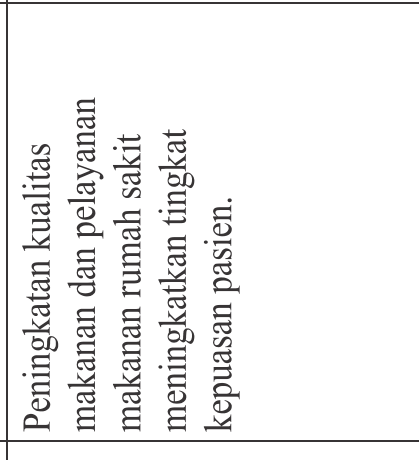 & 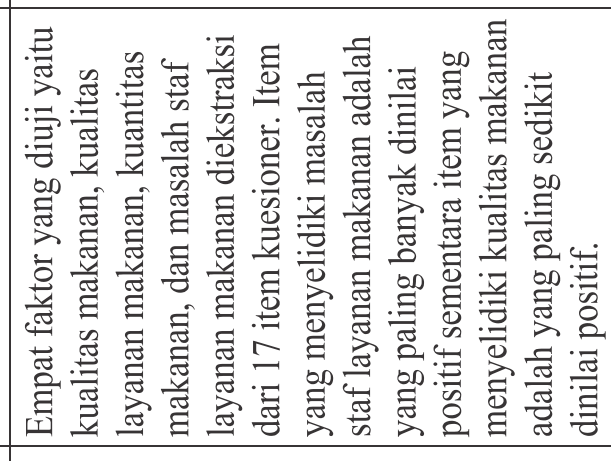 & 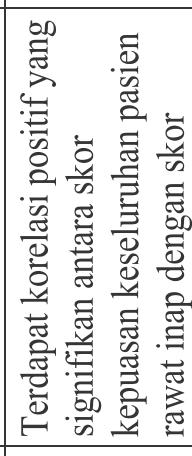 \\
\hline 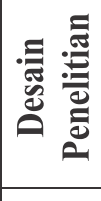 & 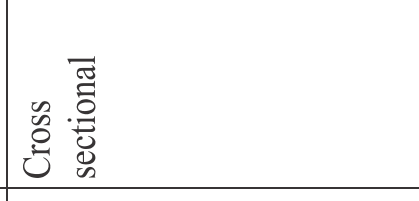 & 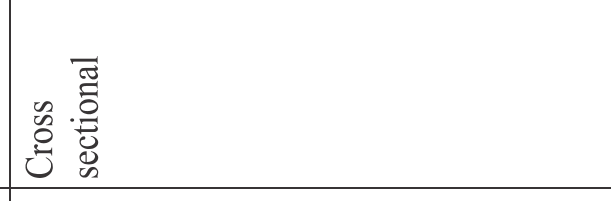 & 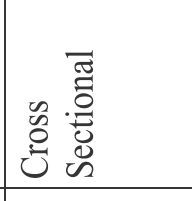 \\
\hline 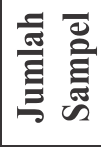 & ì & $\bar{\alpha}$ & $\stackrel{n}{\varrho}$ \\
\hline 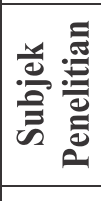 & 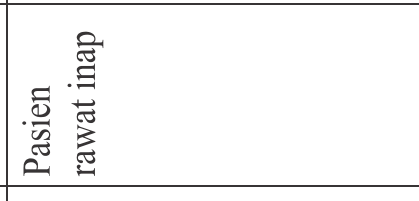 & 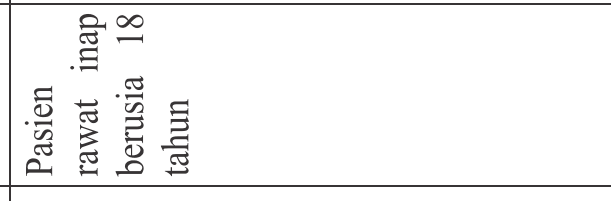 & 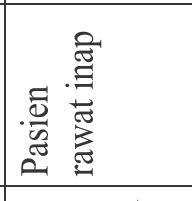 \\
\hline 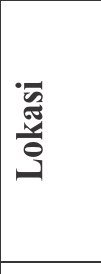 & 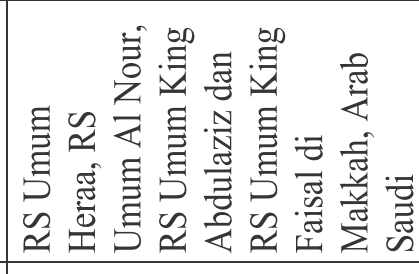 & 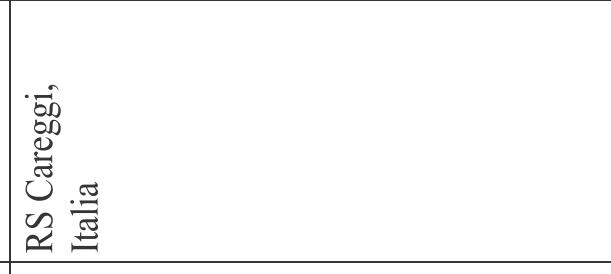 & 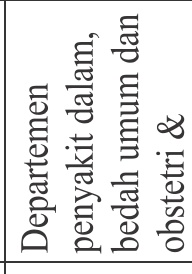 \\
\hline 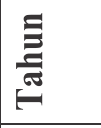 & ㄱ. & ָั & 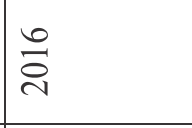 \\
\hline 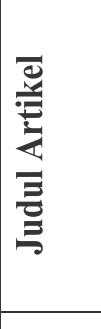 & 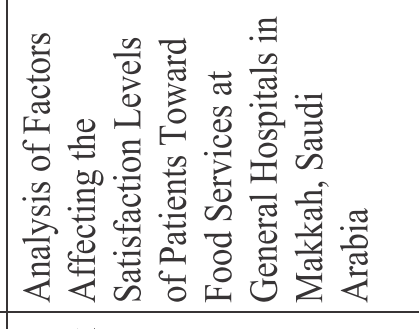 & 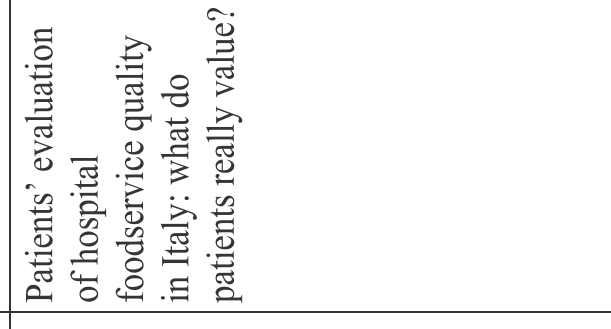 & 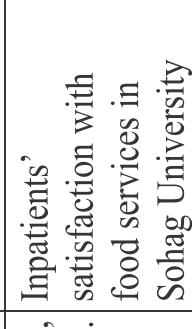 \\
\hline 昜 & 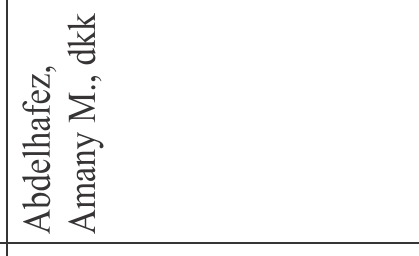 & 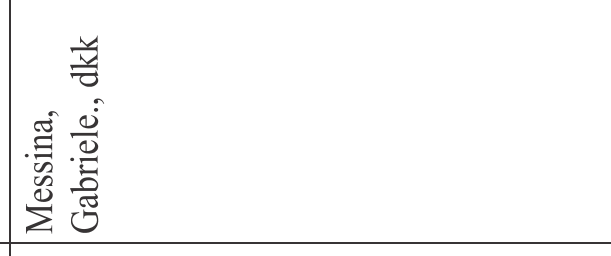 & 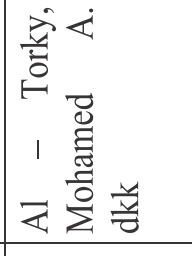 \\
\hline$\dot{z}$ & - & $i$ & $\dot{m}$ \\
\hline
\end{tabular}


Zidni Ilma Nafi'a : Faktor Kepuasan Pasien Terhadap Pelayanan Makanan ....

\begin{tabular}{|c|c|c|c|c|}
\hline 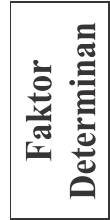 & & 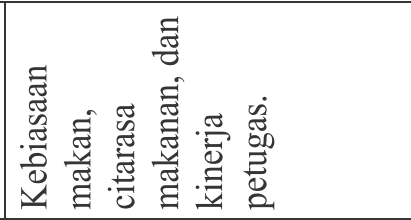 & 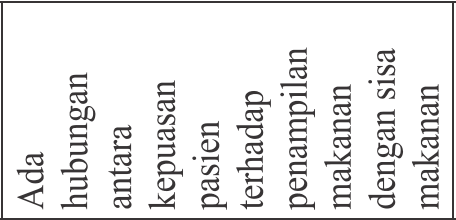 & 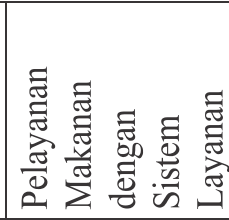 \\
\hline 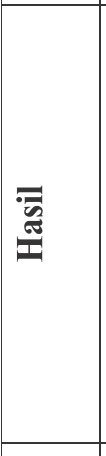 & 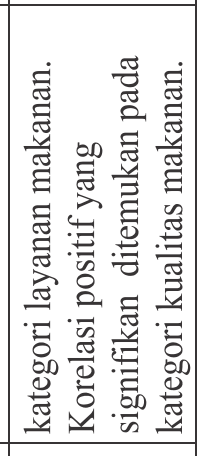 & 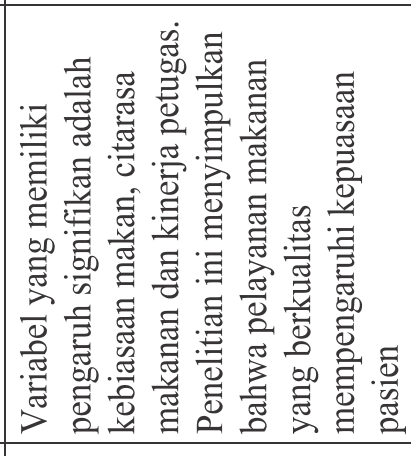 & 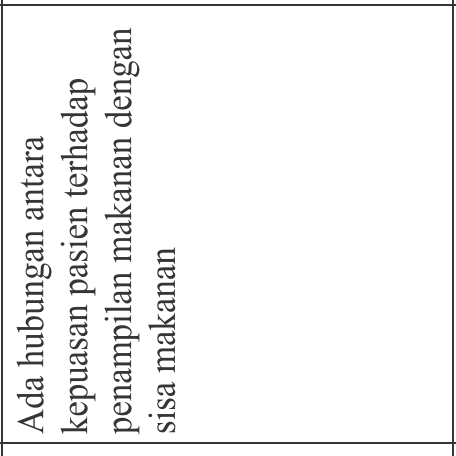 & 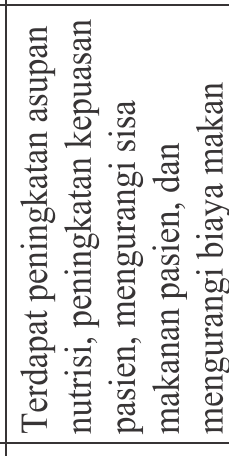 \\
\hline 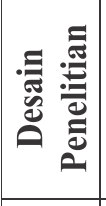 & & 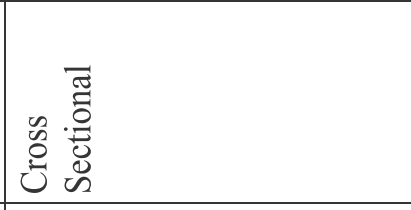 & 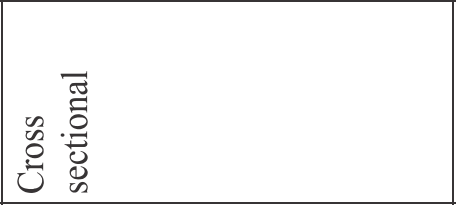 & 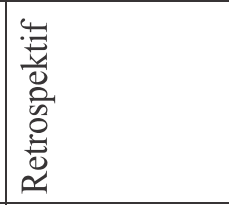 \\
\hline 离灾 & & in & in & $\stackrel{\infty}{\stackrel{\infty}{ \pm}}$ \\
\hline 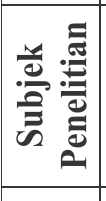 & & 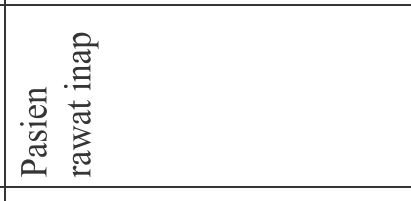 & 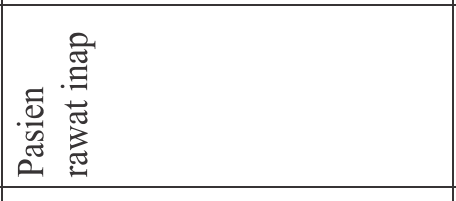 & 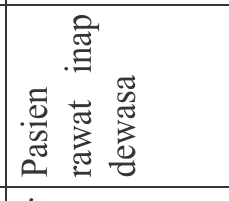 \\
\hline 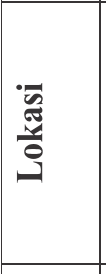 & 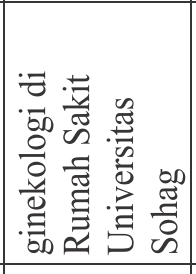 & 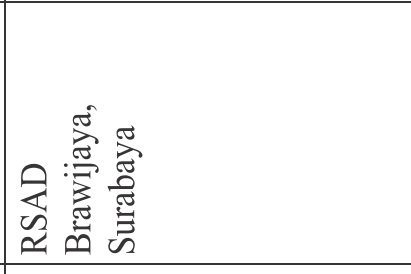 & 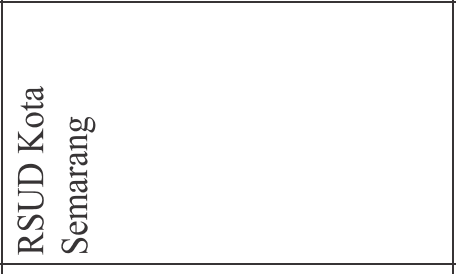 & 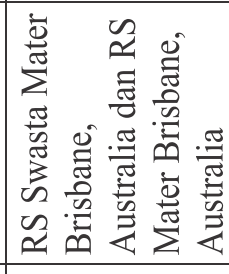 \\
\hline 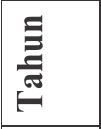 & & 혹 & $\overrightarrow{\bar{i}}$ & $\infty$ \\
\hline 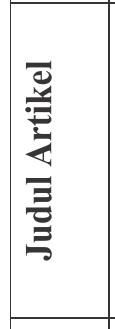 & 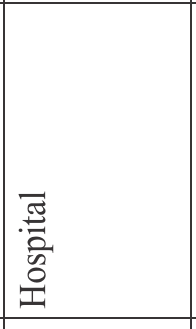 & 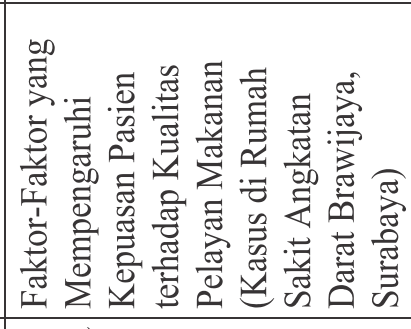 & 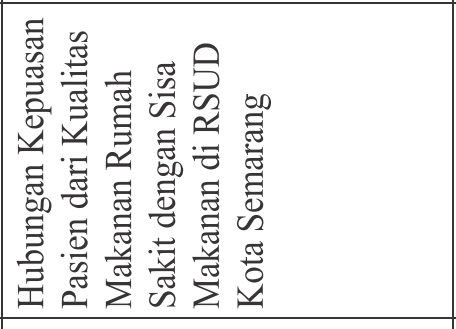 & 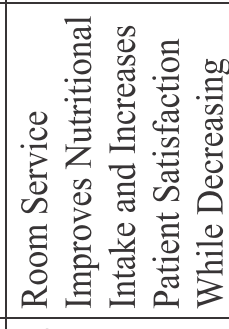 \\
\hline 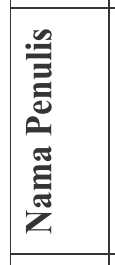 & & 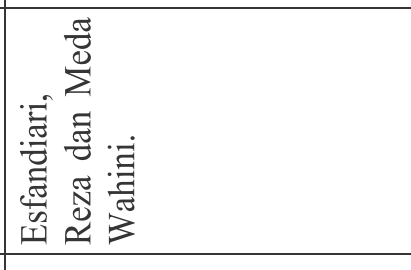 & 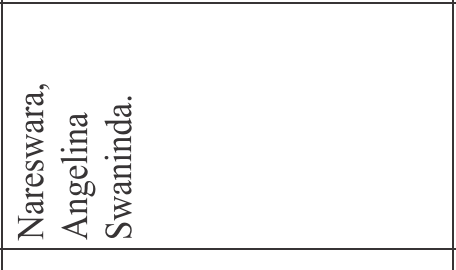 & 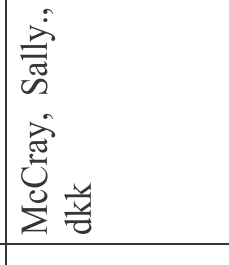 \\
\hline 8 & & $\dot{+}$ & in & 0 \\
\hline
\end{tabular}


Jurnal Manajemen Kesehatan Yayasan RS. Dr. Soetomo Vol.7 No.2 Oktober 2021: 233-247

\begin{tabular}{|c|c|c|c|}
\hline 音高 & 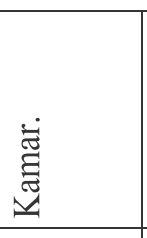 & 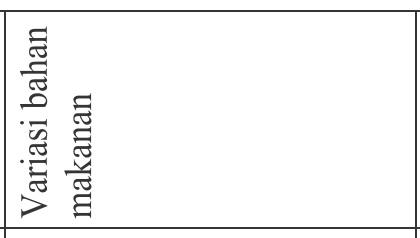 & 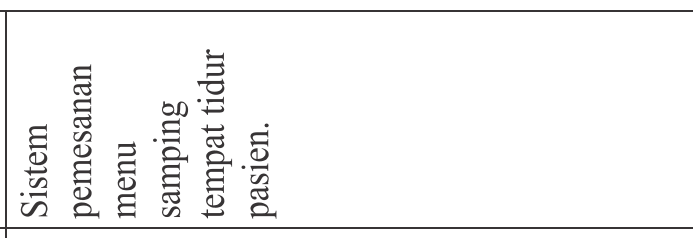 \\
\hline 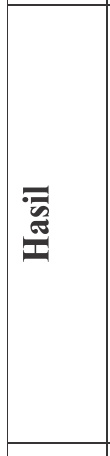 & 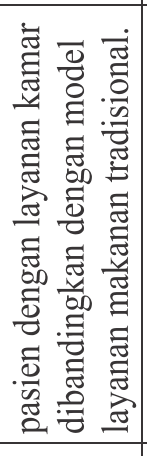 & 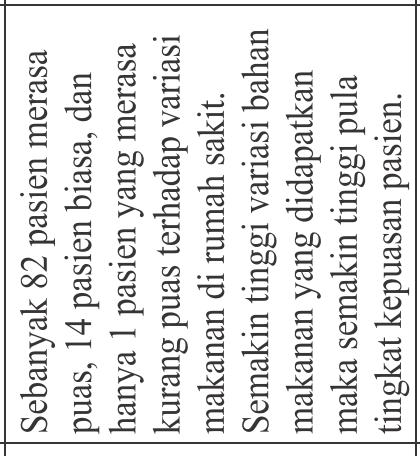 & 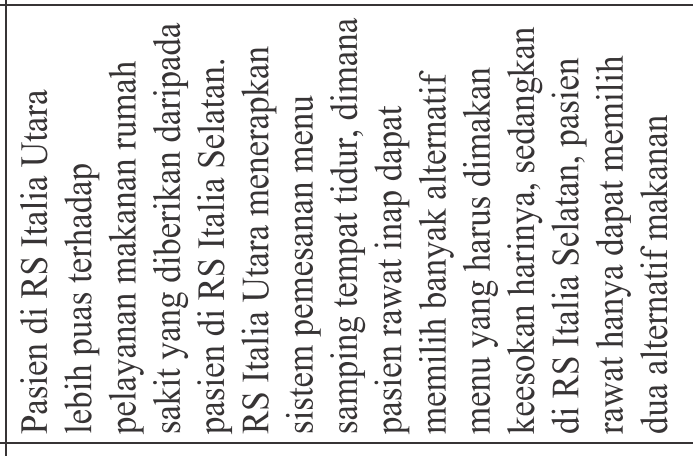 \\
\hline 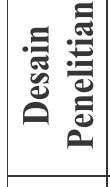 & & 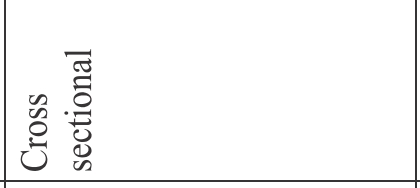 & 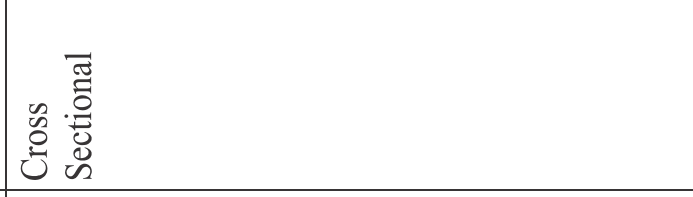 \\
\hline 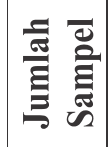 & & $\hat{a}$ & 号 \\
\hline 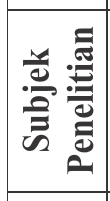 & & 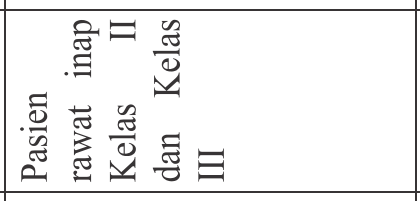 & 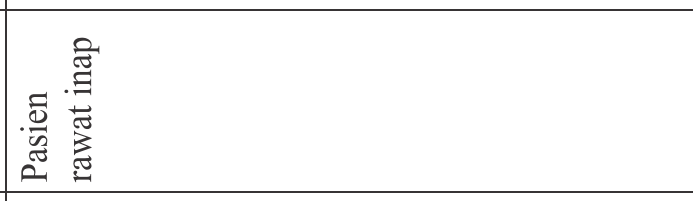 \\
\hline 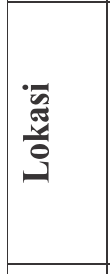 & & 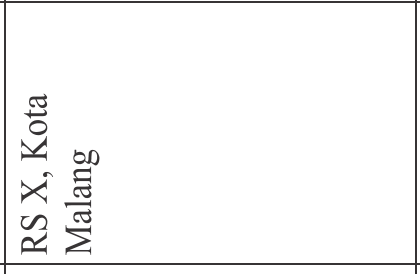 & 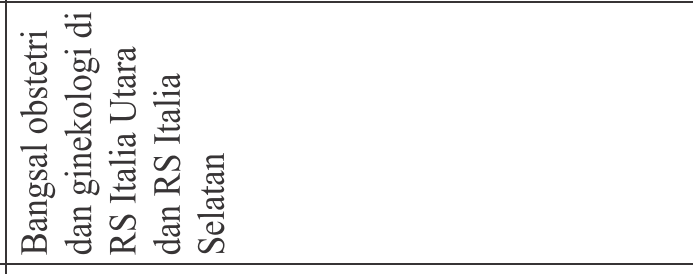 \\
\hline 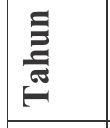 & & 亏े & ๙ิ \\
\hline 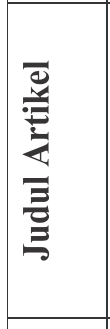 & 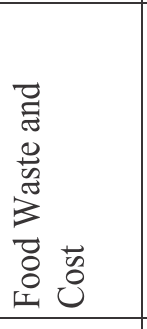 & 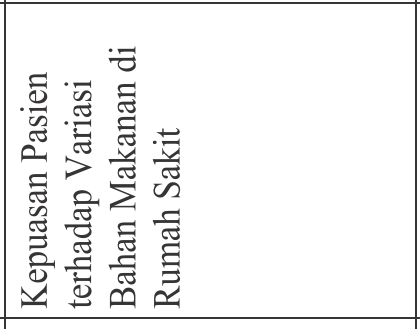 & 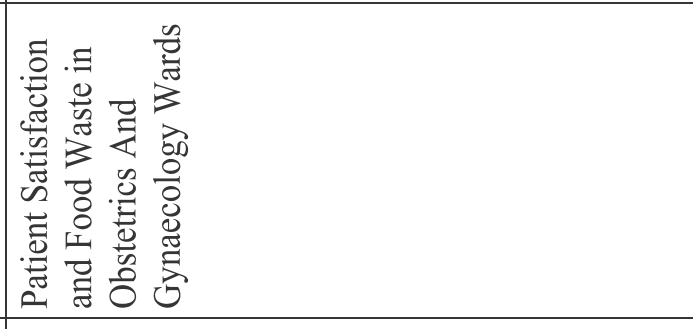 \\
\hline 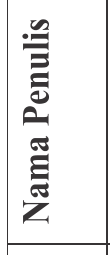 & & 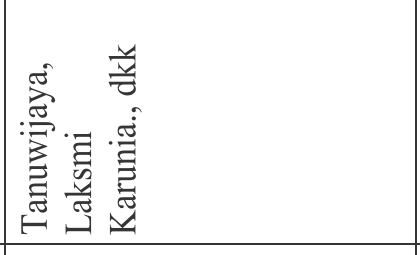 & 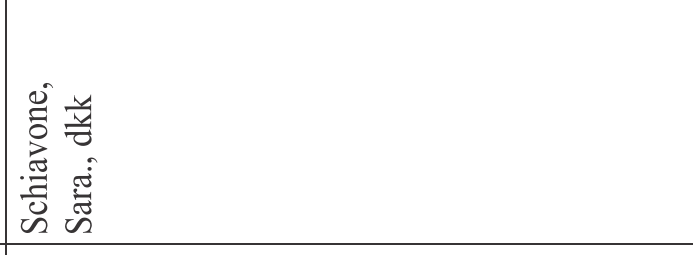 \\
\hline$\dot{\mathbf{z}}$ & & $\therefore$ & $\infty$ \\
\hline
\end{tabular}


Zidni Ilma Nafi'a : Faktor Kepuasan Pasien Terhadap Pelayanan Makanan ....

\begin{tabular}{|c|c|c|}
\hline 童 & 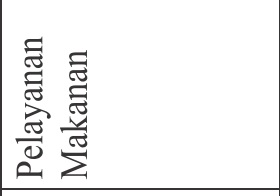 & 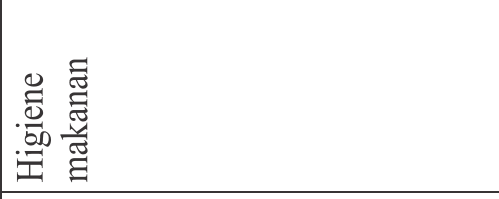 \\
\hline 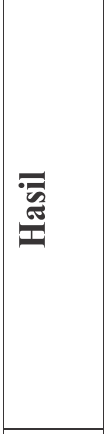 & 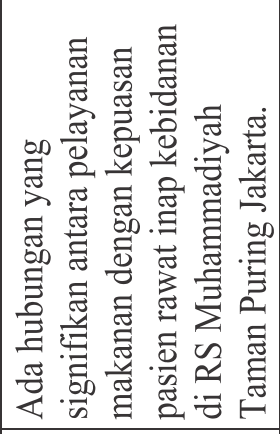 & 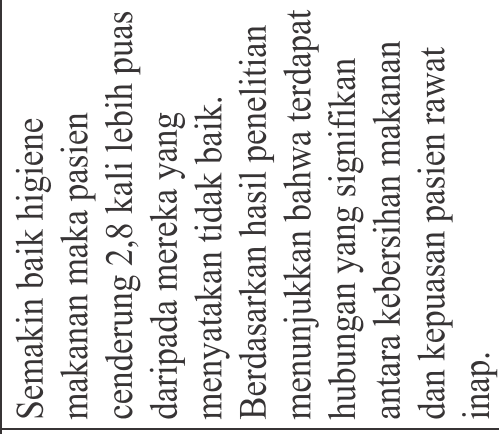 \\
\hline 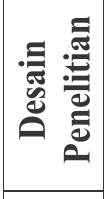 & r & 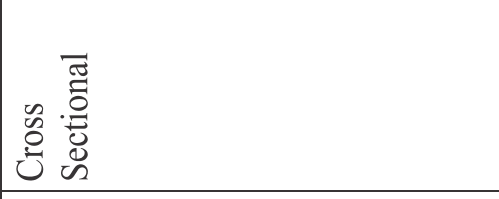 \\
\hline 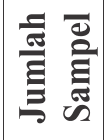 & $\bar{\gamma}$ & $\cong$ \\
\hline 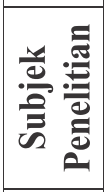 & 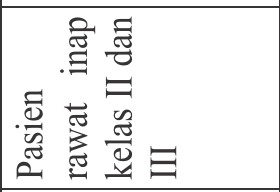 & 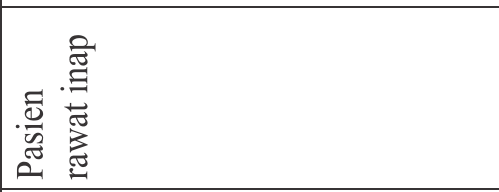 \\
\hline $\begin{array}{l}\overline{0} \\
\frac{5}{5} \\
\frac{\pi}{0} \\
\end{array}$ & 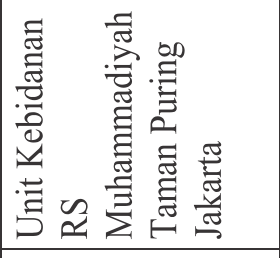 & 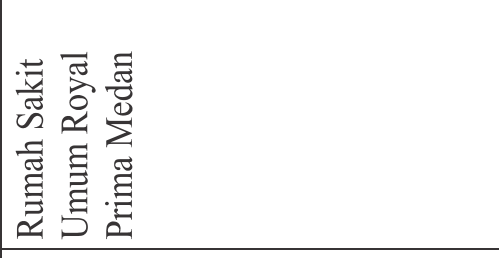 \\
\hline 志 & ণి & ণి \\
\hline 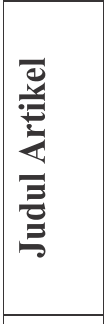 & 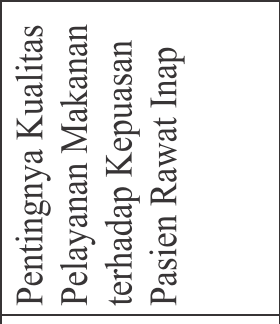 & 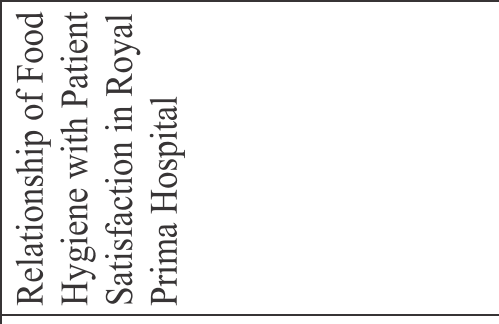 \\
\hline 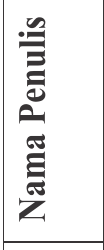 & 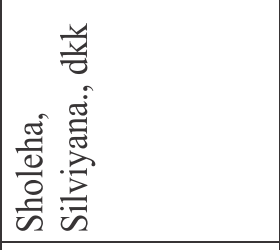 & 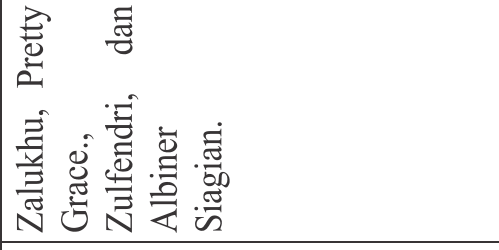 \\
\hline$\dot{z}$ & $\sigma^{\circ}$ & $\stackrel{0}{0}$ \\
\hline
\end{tabular}




\section{PEMBAHASAN}

Berdasarkan telaah dari 10 artikel yang diperoleh, terdapat dua kelompok faktor yang mempengaruhi kepuasan pasien terhadap pelayanan makanan di rumah sakit. Kedua kelompok tersebut adalah kualitas makanan dan kualitas layanan makanan. Kualitas makanan dan pelayanan makanan memiliki sub faktor yang lebih rinci yang akan dibahas sebagai berikut.

\section{Kualitas Makanan}

Penelitian di RS Umum Makkah Saudi Arabia menunjukkan bahwa peningkatan kualitas makanan dan pelayanan makanan rumah sakit meningkatkan tingkat kepuasan pasien (M. Abdelhafez et al., 2012). Kualitas makanan meliputi semua keunikan dan keunggulan yang membuat pembeli atau calon konsumen merasa cocok. Ada berbagai faktor yang berkontribusi terhadap kualitas makanan seperti rasa, warna, kenampakan, kesegaran, bau, nilai gizi, bahan, dan kontaminan (Busra et al., 2017). Orang cenderung akan memberi kesan pertamanya terhadap suatu makanan dari unsur rasa dan penampilan. Hal tersebut sejalan dengan penelitian di RS King Abdul Aziz bahwa rasa dan penampilan makanan menjadi unsur kualitas makanan yang mempengaruhi kepuasan pasien dan berkontribusi terhadap kepuasan pasien (Bin-Ashwan, 2016). Selain itu, kualitas makanan rumah sakit dirasa menjadi faktor penting kepuasan pasien di rumah sakit yang dapat diakui internasional, hal tersebut dikarenakan kualitas makanan tidak hanya menjadi penentu kepuasan pasien di Indonesia, tetapi juga di negara lain seperti penelitian di RS Universitas Sohag mengemukakan terdapat korelasi positif yang signifikan antara skor kepuasan keseluruhan pasien rawat inap dengan skor kategori layanan makanan. Korelasi positif yang signifikan ditemukan pada kategori kualitas makanan (Al-torky et al., 2016). Adapun aspek kualitas makanan yang menjadi penentu kepuasan pasien di rumah sakit di Italia adalah berupa rasa, penyajian, persiapan, dan variasi adalah unsur terbaik dari keseluruhan unsur kepuasan (Messina et al., 2013).

Unsur kualitas makanan tertentu secara khusus juga dapat mempengaruhi kepuasan pasien terhadap pelayanan makanan di rumah sakit, salah satunya variasi makanan. Variasi makanan memang merupakan hal yang krusial, karena pasien dengan rentang waktu rawat inap yang cukup lama mungkin akan mengalami kebosanan karena pengulangan menu makanan, tentunya hal tersebut harus diatasi dengan melakukan variasi makanan. Hal tersebut sejalan dengan penelitian di sebuah rumah sakit di Kota Malang yang mana menunjukkan semakin tinggi variasi bahan makanan yang didapatkan maka semakin tinggi pula tingkat kepuasan pasien (Tanuwijaya et al., 2019). 
Zidni Ilma Nafi'a : Faktor Kepuasan Pasien Terhadap Pelayanan Makanan ....

\section{Kualitas Layanan Makanan}

Tidak selalu tentang rasa dan variasi makanan yang menjadi faktor kepuasan pasien dalam pelayanan makanan di rumah sakit, tetapi terdapat unsur kualitas makanan lainnya yang menjadi penentu kepuasan pasien yaitu higiene atau kebersihan makanan, hal tersebut berdasarkan penelitian di RS Royal Prima Medan yang mana diperoleh hasil semakin baik higiene makanan maka pasien cenderung 2,8 kali lebih puas daripada mereka yang menyatakan tidak baik (Zalukhu et al., 2020). Higiene atau kebersihan makanan menjadi bagian yang penting bagi pasien hal tersebut sesuai dengan hasil evaluasi pada pasien di Rumah Sakit di Athena yaitu 90,8\% pasien menyarankan penggunaan sarung tangan selama penyajian yang mana menunjukkan bahwa pasien peduli dengan kebersihan makanan dan tentunya akan berpengaruh terhadap kepuasan pasien (Mentziou et al., 2014). Unsur kualitas makanan lainnya yang menjadi penentu kepuasan pasien adalah penampilan makanan. Hal tersebut sesuai dengan penelitian di RSUD Kota Semarang yang mana diperoleh hubungan antara kepuasan pasien terhadap penampilan makanan dengan sisa makanan (Nareswara, 2017).

Kualitas makanan tidak selalu menjadi kelompok tunggal penentu kepuasan pasien dalam pelayanan makanan di rumah sakit, kedua kelompok sekaligus dalam hal ini kualitas makanan dan kualitas layanan makanan dapat menjadi faktor signifikan kepuasan pasien, hal tersebut berdasarkan penelitian di RSAD Brawijaya Malang yang menunjukkan bahwa citarasa makanan dan kinerja petugas berpengaruh signifikan terhadap kepuasan pasien (Esfandiari \& Wahini, 2017). Citarasa merupakan unsur kualitas makanan sedangkan kinerja petugas merupakan unsur pelayanan makanan. Penelitian lain juga menunjukkan hal serupa yaitu karakteristik makanan yang berupa rasa, penampilan, variabilitas dan kehangatan atau suhu dan distribusi makanan yang mencakup penggunaan sistem troli curah, waktu distribusi makanan, jumlah, kebersihan alat makan, sikap dan perilaku petugas merupakan faktor yang berpengaruh terhadap kepuasan pasien (Mangunsong \& Junadi, 2018).

Pelayanan makanan dapat dikatakan sebagai rangkaian proses dalam penyediaan makanan bagi pasien dimulai sejak makanan akan diproduksi sampai makanan selesai dikonsumsi oleh pasien. Kualitas pelayanan makanan ternyata turut menjadi faktor kepuasan pasien. Hal tersebut berdasarkan penelitian di RS Muhammadiyah Taman Puring Jakarta yang mana terdapat hubungan yang signifikan antara pelayanan makanan dengan kepuasan pasien rawat inap kebidanan di RS Muhammadiyah Taman Puring Jakarta (Sholeha et al., 2020). Model layanan makanan rumah sakit semakin berubah 
untuk memenuhi berbagai indikator kinerja utama dalam kesehatan sehingga pengukuran manfaat layanan makanan yang komprehensif menjadi sangat penting (McCray et al., 2018). Salah satu model layanan makanan rumah sakit yang kini mulai muncul yaitu layanan kamar yaitu pasien dapat memilih sendiri makanan yang ingin dikonsumsi dan dapat mengatur sendiri waktu makan yang diinginkan. Suatu penelitian di RS Swasta Mater Brisbane Australia dan RS Mater Brisbane Australia menunjukkan terdapat peningkatan asupan nutrisi, peningkatan kepuasan pasien, mengurangi sisa makanan pasien, dan mengurangi biaya makan pasien di RS Swasta Mater Brisbane yang mana menerapkan layanan makanan kamar dibandingkan dengan di RS Mater Brisbane Australia yang notabene masih menggunakan model layanan makanan tradisional (McCray et al., 2018). Penelitian serupa juga dilakukan di RS Italia Utara dan RS Italia Selatan yang mana menunjukkan hasil yang sama dimana pasien di RS Italia Utara lebih puas terhadap pelayanan makanan rumah sakit yang diberikan daripada pasien di RS Italia Selatan. RS Italia Utara menerapkan sistem pemesanan menu samping tempat tidur, dimana pasien rawat inap dapat memilih banyak alternatif menu yang harus dimakan keesokan harinya, sedangkan di RS Italia Selatan, pasien rawat inap hanya dapat memilih dua alternatif makanan (Schiavone et al., 2020). Adapun di Indonesia penelitian tentang layanan kamar pada pelayanan makanan pasien pernah dilakukan di RSUD Waled, Cirebon, Jawa Barat yang mana pasien dengan layanan kamar memiliki tingkat kepuasan 12,11 kali dan daya terima 2,38 kali lebih baik dibandingkan dengan pasien biasa atau layanan konvensional (Iqbal et al., 2016). Selain penerapan sistem layanan kamar hal sederhana yang tidak perlu biaya besar dapat meningkatkan kepuasan pasien yaitu dengan meningkatkan visual penyajian makanan seperti menambah hiasan pada nampan makan pasien. Penelitian yang dilakukan di Pusat Kesehatan E. Wolfson Holon, Israel menunjukkan bahwa dengan menambahkan hiasan serbet oranye ke nampan makan, tidak hanya dapat meningkatkan konsumsi makanan pasien, tetapi juga dapat meningkatkan skor kepuasan layanan makanan (Navarro et al., 2019).

\section{SIMPULAN}

Pelayanan makanan di rumah sakit merupakan bagian pelayanan kesehatan di rumah sakit yang memiliki sumbangsih terhadap kepuasan pasien khususnya pasien rawat inap. Kualitas makanan dan kualitas pelayanan makanan di rumah sakit menjadi dua hal yang paling menentukan dalam kepuasan pasien terhadap pelayanan makanan di rumah sakit. Secara garis besar kualitas makanan adalah hal yang berhubungan dengan rasa, 
tektstur, penampilan, dan variasi makanan sedangkan kualitas pelayanan makanan adalah hal yang berhubungan dengan sistem pemesanan makanan, alat makan, sikap dan kinerja petugas. Berdasarkan hal tersebut kini rumah sakit dirasa perlu banyak melakukan evaluasi dan penilaian di sektor kualitas makanan dan kualitas pelayanan makanan supaya meningkatkan kepuasan pasien.

\section{UCAPAN TERIMA KASIH}

Terima kasih kepada dosen Pembimbing dan Fakultas Kesehatan Masyarakat, Universitas Ahmad Dahlan dan beserta para staf yang telah membantu proses penelitian ini sehingga berjalan dengan baik.

\section{DAFTAR PUSTAKA}

Al-torky, M. A., Mohamed, E. A., Yousef, F. M. A., \& Ali, N. A. (2016). Inpatients' Satisfaction with Food Services in Sohag University Hospital. The Egyptian Journal of Community Medicine, 34(2), 33-45. https://doi.org/10.21608/ejcm.2016.651

Arifiyanti, A. L., Djamaludin, R., \& Achmad. (2017). Upaya Peningkatan Kepuasan Pasien di Instalasi Farmasi Rumah Sakit Islam Surabaya Tahun 2016. JURNAL MANAJEMEN KESEHATAN Yayasan RS Dr. Soetomo, 03(1), 123-137.

Bin-Ashwan, D. A. (2016). Analysis Of Variables Affecting the Satisfaction Levels Of Patients Toward Food Services at King Abdulaziz Hospital, Ministry Of National Guards.Ward 6(Business Center \& Mpd).Alhassaeastern Region,.Kingdom Of Saudi Arabia. International Journal of Education and Research, 4(11), 47-66.

Busra, N. N., Dolah, S. N., Che Ngah, H., \& Samsudin, A. (2017). Government Hospitals Food Quality and Patient Satisfaction. Journal of Tourism, Hospitality \& Culinary Arts, 9(2), 593-602.

Esfandiari, R., \& Wahini, M. (2017). Faktor-Faktor yang Mempengaruhi Kepuasan Pasien terhadap Kualitas Pelayan Makanan (Kasus di Rumah Sakit Angkatan Darat Brawijaya, Surabaya). E-Journal Boga, 5(2), 18-24.

Iqbal, M., Susetyowati, S., \& Purba, M. B. (2016). The Effects of Room Service to Improve Patients' Food Satisfaction and Food Acceptance. Gizi Indonesia, 39(2), 103-114. https://doi.org/10.36457/gizindo.v39i2.213

Karunia Tanuwijaya, L., Gresari Sembiring, L., Yanuar Dini, C., Putri Arfiani, E., \& Arimba Wani, Y. (2018). Sisa Makanan Pasien Rawat Inap: Analisis Kualitatif. Indonesian Journal of Human Nutrition, 5(1), 51-61. https://doi.org/10.21776/ub.ijhn.2018.005.01.6

M. Abdelhafez, A., Al Qurashi, L., Al Ziyadi, R., Kuwair, A., Shobki, M., \& Mograbi, H. (2012). Analysis of Factors Affecting the Satisfaction Levels of Patients Toward Food Services at General Hospitals in Makkah, Saudi Arabia. American Journal of Medicine and Medical Sciences, 2(6), 123-130. 
https://doi.org/10.5923/j.ajmms.20120206.03

Mangunsong, E. R., \& Junadi, P. (2018). Patient Satisfaction Contributing Factors on Hospital Food Service: A Systematic Review. International Journal of Management and Applied Science, 4(1), 1-10. http://

McCray, S., Maunder, K., Krikowa, R., \& MacKenzie-Shalders, K. (2018). Room Service Improves Nutritional Intake and Increases Patient Satisfaction While Decreasing Food Waste and Cost. Journal of the Academy of Nutrition and Dietetics, 118(2), 284-293. https://doi.org/10.1016/j.jand.2017.05.014

Mentziou, I., Delezos, C., Nestoridou, A., \& Boskou, G. (2014). Evaluation of Food Services by the Patients in Hospitals of Athens in Greece. Health Science Journal, 8(3), 383-392.

Messina, G., Fenucci, R., Vencia, F., Niccolini, F., Quercioli, C., \& Nante, N. (2013). Patients' Evaluation of Hospital Foodservice Quality in Italy: What do Patients Really Value? Public Health Nutrition, 16(4), 730-737. https://doi.org/10.1017/S1368980012003333

Nareswara, A. S. (2017). Hubungan Kepuasan Pasien dari Kualitas Makanan Rumah Sakit dengan Sisa Makanan di RSUD Kota Semarang. Ilmu Gizi Indonesia, 01(01), 34-39.

Navarro, D. A., Shapiro, Y., Birk, R., \& Boaz, M. (2019). Orange Napkins Increase Food Intake and Satisfaction with Hospital Food Service: A Randomized Intervention. Nutrition: $\quad X, \quad 3(4), \quad 1-6$. https://doi.org/10.1016/j.nutx.2020.100008

Ramesh, \& Manimegalai. (2018). Uniqueness of Hospital Food Service. International Journal of Development Research, 08(07), 21724-21732.

Schiavone, S., Pistone, M. T., Finale, E., Guala, A., \& Attena, F. (2020). Patient Satisfaction and Food Waste in Obstetrics and Gynecology Wards. Patient Preference and Adherence, 14, 1381-1388. https://doi.org/10.2147/PPA.S277267

Sholeha, S., Kusindrati, K., Tanuwijaya, R. R., \& Marini, R. (2020). Pentingnya Kualitas Pelayanan Makanan terhadap Kepuasan Pasien Rawat Inap. Jurnal Ilmiah Kesehatan, 19(2), 55-58. https://doi.org/10.33221/jikes.v19i02.513

Simanjuntak, L. M. A., Aulia, D., \& Siagian, A. (2020). Patients' Perceptions of food Service Quality at Royal Prima Hospital Medan. Britain International of Exact Sciences (BIoEx) Journal, 2(1), 197-209. https://doi.org/10.33258/bioex.v2i1.128

Tanuwijaya, L. K., Novitasari, T. D., Arifiani, E. P., Wani, Y. A., \& Wulandari, D. E. (2019). Kepuasan Pasien terhadap Variasi Bahan Makanan di Rumah Sakit. Jurnal Gizi, 8(1), 50-58. https://www.researchgate.net/publication/326122173_Sisa_Makanan_Pasien _Rawat_Inap_Analisis_Kualitatif/download

Yuwono, S. R., Taher, A., Minarto, Irianto, S. E., Thaha, A. ., Agus, Wijaya, A. M., Mursita, A., Hermani, A., Trisusila, A., Anom, Ario, Amin, A. M., Harianto, B., Cornelia, Rosa, D., Deviyana, Astuti, D., Indriarti, D. W., ... Fina. (2013). Pedoman Pelayanan Gizi Rumah Sakit. Kementerian Kesehatan Republik Indonesia. 
Zidni Ilma Nafi'a : Faktor Kepuasan Pasien Terhadap Pelayanan Makanan ....

Zalukhu, P. G., Zulfendri, \& Siagian, A. (2020). Relationship of Food Hygiene with Patient Satisfaction in Royal Prima Hospital. Britain International of Exact Sciences (BIoEx) Journal, 2(1), 357-367. https://doi.org/10.33258/bioex.v2i1.165

\begin{tabular}{|l|l|}
\hline Submission & $19-06-2021$ \\
\hline Review & $21-06-2021$ \\
\hline Accepted & $25-09-2021$ \\
\hline Publish & $29-10-2021$ \\
\hline DOI & $10.29241 /$ jmk.v7i2.634 \\
\hline Sinta Level & 3 (Tiga) \\
\hline
\end{tabular}

